Received: $29 / 10 / 2018$

Revision: $22 / 03 / 2019$

Accepted: $27 / 03 / 2019$

OnlineFirst:14/04/2019

\title{
The Effect of Using Synectics Model on Creative Thinking and Metacognition Skills of Junior High School Students
}

\section{Suratno}

Prof, Faculty of Teacher Training and Education, University of Jember, Jember, Indonesia, suratno.fkip@unej.ac.id

\section{Nurul Komaria}

M.Pd, Graduate Student of Sains Education, Faculty of Teacher Training and Education, University of Jember, Jember, Indonesia, nurulqomariah2202@gmail.com

\section{Yushardi}

Dr, Faculty of Teacher Training and Education, University of Jember, Jember, Indonesia, yus_agk.fkip@unej.ac.id

\section{Dafik}

Prof, Faculty of Teacher Training and Education, University of Jember, Jember, Indonesia,d.dafik@gmail.com

\section{Iwan Wicaksono}

Dr, Faculty of Teacher Training and Education, University of Jember, Jember, Indonesia, iwanwicaksono.fkip@unej.ac.id

This study aims (a) to determine the effect of synectics model on creative thinking skill (b) to determine the effect of synectics model on metacognition skill. (c) to find out the relationship between creative thinking and metacognition skills. This study uses a quasi-experimental type with one group pretest posttest design. The study population was 612 junior high school students with a total sample of 242 . The instruments used consisted of essay tests which were assessed using the rubric of creative thinking skills and questionnaires about metacognition skill. Data were analyzed based on parametric statistical calculations. The results showed that the synectics model had an effect on creative thinking and metacognition skills. The results of the correlation analysis show $\mathrm{R}$ of 0.873 . Based on the regression line equation $\mathrm{Y}=12.27+0.8847 \mathrm{x}$, that every 1 -point increase in the score of metacognition skill results in an increase of 0.8847 creative thinking skill.

Keywords: synectics model, creative thinking skill, metacognition skill, thinking, skill

Citation: Suratno, Komaria, N., Yushardi, Dafik, \& Wicaksono, I. (2019). The Effect of Using Synectics Model on Creative Thinking and Metacognition Skills of Junior High School Students. International Journal of Instruction, 12(3), 133-150. https://doi.org/10.29333/iji.2019.1239a 


\section{INTRODUCTION}

Today we are in the 21 st century, where the learning process is transformed to enable students to master knowledge and various skills to compete in the global economy. To meet this challenge, the quality of learning should be improved. The quality of learning can be improved by changing the paradigm in learning, particularly in science lessons, namely from Teacher Centered Learning (TCL) to Student Centered Learning (SCL) (Nichols, 2017). SCL is expected to encourage students to produce information that has value or meaning to develop new skills (Alismail \& McGuire, 2015), such as critical thinking skill, problem solving, creative thinking skill, metacognition skill, communication, collaboration, innovation and other skills (Johnson, 2009). Another advantage of SCL is that it can be tailored to the unique needs, interests, and aspirations of students. SCL will generate better outcomes if students are involved in an effective learning environment in order to enable students to develop their knowledge and skills as independent learners (Nichols, 2017).

To be an independent learner, appropriate learning approach has to be implemented (Okpara, 2007). Learning approach can be implemented using student-centered learning approach with synectics model. The synectics model is a personal model where each learning process is achieved, making students able to carry out their responsibilities, and that makes teaching more creative for a better quality of life (Ramadhani et al, 2017). Synectics model is suitable to be used in natural science learning because it prioritizes analogy or metaphor activities and it relates learning materials with real-life context which makes it possible for students to be more active and get more experiences in interpreting problems and arousing different ideas to solve various problems, especially the ones that occur in science lessons (Walker, 2013). The learning process of science consists of observation, experiment, and to create collaborative learning environment. That process enables the students to understand the subject easier, to have positive attitude toward knowledge and to improve their creative thinking (Eristi \& Polat, 2017). Therefore, creative thinking and metacognition skills are skills which have to be owned and are needed by every student as well as students' innovation to make creative things (Griffin et al, 2012).

Creative thinking is a high level of thinking ability (Kotzer \& Elran, 2012). There are four patterns of high level of thinking. They are critical thinking, creative thinking, problem-solving, and decision making. Among those four, creative thinking is a basic skill for people to think about science. Thus, it is really important to be applied in the learning especially in science learning (Chan, 2007). (Yusnaeni et al, 2017) argued that creative thinking is a positive action which is an important factor in stimulating the function of the brain and in creating good learning styles. Learning styles influence someone in absorbing and processing information which enable them to influence the result of thinking. Someone's overall aspects such as physical development, cognitive/ intellectual, emotional, and spiritual developments which are developed optimally can be the determining factors which determine their success in the future. Cognitive development is considered as important because it is often related to children intelligence. Cognitive skill continues to grow along with the educational process and 
influence of physical developmental factor especially on the brain biologically. The management and organization of cognitive ability are used to respond a problem. Someone can give appropriate response to a problem if he has the ability to think and he is aware of how to manage it (Schraw \& Moshman, 1995).

The ability to manage a thinking process is known as metacognition skill. Metacognition skill is simply called as "thinking about thinking" or thinking about the process of thinking (Flavell, 1979). Someone used his metacognition ability optimally if he is able to control the way he thinks about his thinking by monitoring and assessing something learned. Nowadays, metacognition skill is rarely applied in the learning process. That happens because of teachers' lack of knowledge. They do not realize that metacognition skill can influence students' learning process in order to make them be successful learners, individuals who believe themselves, as well as responsible citizen. Thus, it is important to be applied in various lessons to help students to develop their creativity in order to be creative in solving problems (Cachia et al, 2010).

Creative thinking skill and metacognition skill are related. To improve creative thinking skill someone can regulate themselves. A result of a study conducted by Coutinho (2006) stated that there is significant correlation between cognitive and metacognition needs. It is because someone's metacognition skill can manage their cognitive activity (Kaufman, 2016). Developing metacognition skill is a precious learning goal because that skill can help students to be independent learners. Through synectics model, it is expected that creative thinking and metacognition skills can be developed because they are related. Therefore, the researcher conducted a study on "the effect of using synectics model on creative thinking and metacognition skills of junior high school students. This study aims (a) to determine the effect of synectics model on creative thinking skill (b) to determine the effect of synectics model on metacognition skill. (c) to find out the relationship between creative thinking and metacognition skills.

\section{METHOD}

We apply the triangulation method that combines qualitative and quantitative methods. The quantitative method aims to analyze the data taken from the creative thinking skill rubric test and questionnaire on metacognition skills after the application of the synectics model, while the qualitative method aims to analyze data taken from observations and interviews with selected students. This study investigated two variables, consisting of the implementation of the synectics model as an independent variable and the test of creative thinking skill and student metacognition skill as the dependent variable. To find out in depth the effects of the implementation of the synectics model, we continued the research by sharing observations with all students from the experimental class and selecting several students to be interviewed about their understanding process.The experimental design of this study was to prepare eight experimental class groups. 


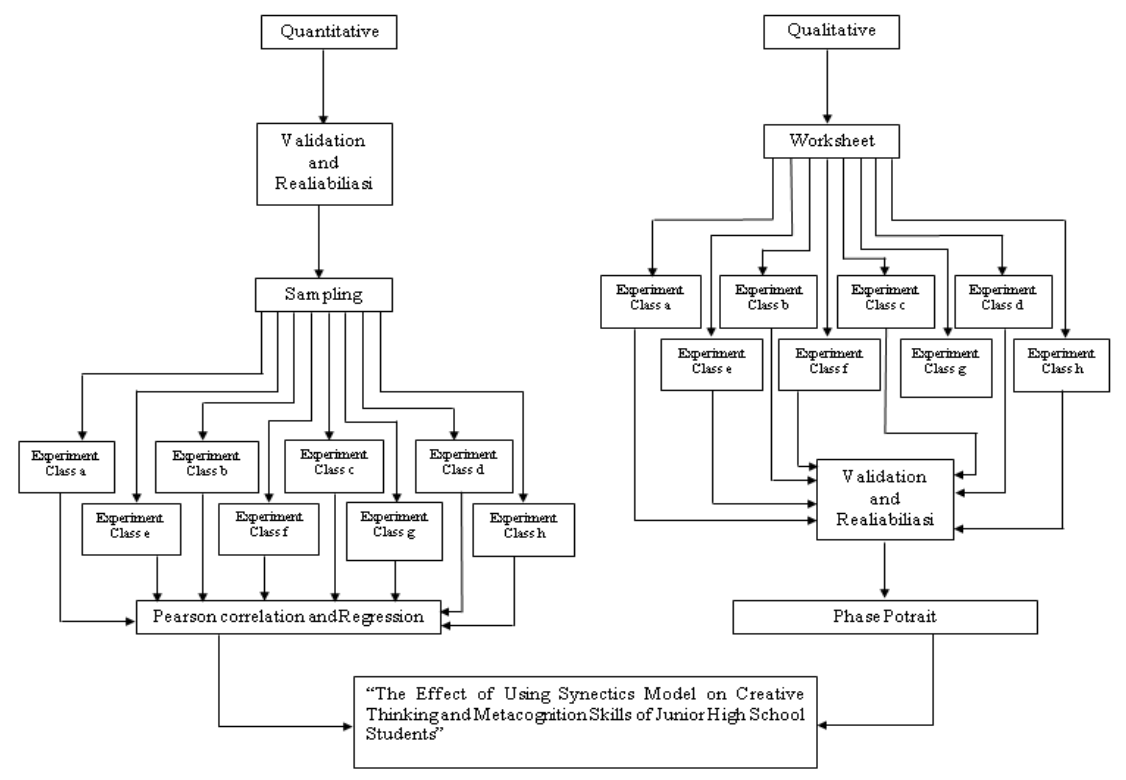

This type of research is a quasi-experimental study with one group pretest posttest design. This study does not use a comparison class but has used the initial test so that the magnitude of the effect of using the synectic model can be known with certainty. In this study, the research subjects were given the initial test (pretest) to determine the extent of students' initial abilities before being given science learning using the synectic model. After being given the initial test, treatment was given. After completing science learning with the synectic model, then all students are given the final test (posttest) to determine the extent of the influence of learning on creative thinking skills and metacognition skills. Simply put, the research design used can be described as follows:

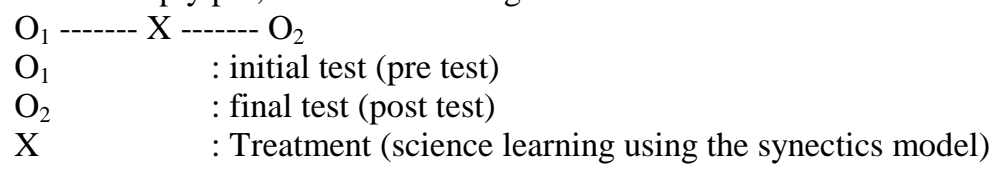

\section{Populasion}

This research was conducted on seventh grade students at the even semester of academic year 2017/2018 for 4 weeks using science material with ecosystem topic. This study involved 242 students from a population of 612 students in 3 junior high schools. The number of the samples was determined based on the Slovin formula using error tolerance $\mathrm{e}=5 \%$, namely [sample $=$ population $/ 1+\left(\right.$ population $\left.\mathrm{x} \mathrm{e} \mathrm{e}^{2}\right)$ ] (Sevilla et al, 1984). The school chosen were SMP Negeri 2 Ajung using 4 testing classes (30students in each class), MTs As-Siddiqy using 2 classes (31 students in each class), and SMP AR-Raudhah using 2 classes (31 students in each class). 
The instrument of this study consisted of essay test which was assessed using a rubric of creative thinking skill and questionnaire on metacognition skill, applied to all of the samples. The implementation of the synectics model in the learning process used syllabus, lesson plan, and student worksheets. The syntax of the synectic learning model consists of (1) substantive input; (2) combining direct analogies, comparing and explaining analogies; (3) personal analogy; (4) exploration; (5) bring out a new analogy. Indicators of creative thinking consist of fluency, flexibility and originality (Weiping \& Philip, 2002). Meanwhile, metacognition skills refer to the MAI questionnaire developed by Scraw, G. \& Dennison, RS (1994) which consists of knowledge about awareness and regulation of consciousness which consists of variable declarative knowledge, procedural knowledge, conditional knowledge, planning, information management strategies, comprehention monitoring, debugging strategies, and evaluation.

\section{Instruments}

The instruments included test, observation, interviews, and observations. The researcher only distributed the observation to all subjects in the experimental class with 10 items done by 10 observers. The observation used a Likert scale encompassing Very Active (Score 5), Active (Score 4), Hesitate (score 3), Inactive (score 2), Very Inactive (score 1). The test, observation, interviews were validated by an expert of mathematics education.

Analysis of the student answers terms of creative thinking skill for each dimension is calculated by tabulation the answers was as follows: The answers in the scope of creative thinking skill for each dimension were categorized by rating scale consisting of very creative $(75 \leq x<96)$, creative $(50 \leq x<75)$, fairly creative $(50 \leq x<25)$, and less creative $(25 \leq \mathrm{x}<0)$ (Fitriani \& Yarmayani, 2018).

Analysis of the students' answers in terms of metacognition skill for each dimension were tabulated according to the alternative choices, namely "always" with 5 points, "very often" with 4 points, "often" with 3 points, "rare" with 2 points, "very rare" with 1 point and "never" with 0 point. The points obtained were converted to a scale of $0-100$. The level of metacognition skill was categorized using rating scale from Green (2002) consisting of super $(85 \leq \mathrm{x}<100)$, good $(68 \leq \mathrm{x}<85)$, developing $(51 \leq \mathrm{x}<68)$, less capable $(34 \leq \mathrm{x}<51)$, at risk $(17 \leq \mathrm{x}<34)$, and not yet developed $(0 \leq \mathrm{x}<17)$.

Analysis of the interaction between creative thinking and metacognition skills of students with synectics models was carried out using scores obtained in the post-test using Pearson Correlation. Furthermore, regression analysis is done to predict the pattern of relationships. The data obtained were analyzed using the SPSS program for Windows Release 23.0. The following chart is presented to provide a clearer design for this study. 


\section{Student Task}

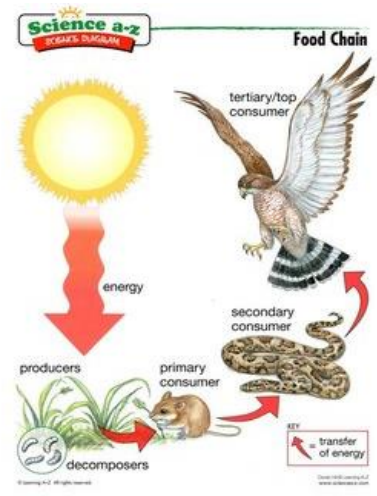

Figure 1 Food Chain

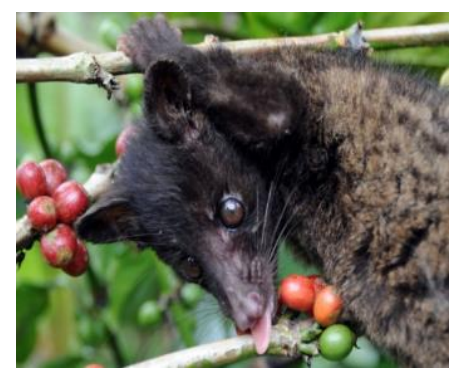

Figure 2

Civet Eats Coffee

In this study, the researcher gave the students the following task related to science learning problems with ecosystem material using synectics model. Based on Figure 2, if coffee plant is extinct, civet can still survive if released in the wild. Why does it happen? Write down the possible food chains. Based on Figure 1 and the analysis of the answer for No. 2, explain the similarities and differences in the two food chains. The purpose of this study to analysis the effect of using synectics model on creative thinking and metacognition skills of junior high school students. We assume that students will face many issues in solving problems. If students can solve them, they will have a lot of experience. Therefore, several questions were chosen to understand important topics.

\section{FINDINGS}

This study aimed (a) to determine the effect of the synectics model on creative thinking skills (b) to determine the effect of the synectics model on metacognition skills. (c) to find out the correlation between creative thinking skills and metacognition skills. The results of this study in the form of profiles of creative thinking and metacognition skill with synectics model are presented in Table 1.

Table 1

The Recapitulation of Sample, Mean, Std. Deviation, Minimum score and Maximum score for Creative Thinking and Metacognition Skills of Students

\begin{tabular}{|c|c|c|c|c|c|c|}
\hline & & $\mathrm{N}$ & Min & Max & Mean & Std. Deviation \\
\hline \multirow{2}{*}{$\begin{array}{l}\text { Creative Thinking } \\
\text { Skill }\end{array}$} & Before & 242 & 45 & 81 & 66.68 & 7.698 \\
\hline & After & 242 & 50 & 85 & 68.14 & 7.384 \\
\hline \multirow{2}{*}{ Metacognition Skill } & Before & 242 & 48 & 84 & 69.86 & 7.399 \\
\hline & After & 242 & 56 & 91 & 72.48 & 7.496 \\
\hline
\end{tabular}

The results showed an increase in the value of creative thinking skills from 81 to 85 , an increase in the value of metacognition skills from 84 to 91 . This means that the synectics 
model has the effect of increasing the value of creative thinking skills and student metacognition skills. The recapitulation result of the correlation between creative thinking and metacognition skills before and after the learning with the synectics model are shown in Table 2.

Table 2

The Recapitulation of Correlation Value between Creative Thinking and Metacognition Skills Before and After Learning with Synectics Model

\begin{tabular}{|c|c|c|c|}
\hline & & Creative Thinking Skill & Metacognition Skill \\
\hline \multicolumn{4}{|l|}{ Before } \\
\hline \multirow{3}{*}{$\begin{array}{l}\text { Creative Thinking } \\
\text { Skill }\end{array}$} & Pearson Correlation & 1 & .718 \\
\hline & Sign. (2-tailed) & & .000 \\
\hline & $\mathrm{N}$ & 242 & 242 \\
\hline \multirow{3}{*}{$\begin{array}{l}\text { Metacognition } \\
\text { Skill }\end{array}$} & Pearson Correlation & .718 & 1 \\
\hline & Sign. (2-tailed) & .000 & \\
\hline & $\mathrm{N}$ & 242 & 242 \\
\hline \multicolumn{4}{|l|}{ After } \\
\hline \multirow{3}{*}{$\begin{array}{l}\text { Creative Thinking } \\
\text { Skill }\end{array}$} & Pearson Correlation & 1 & .873 \\
\hline & Sign. (2-tailed) & & .000 \\
\hline & $\mathrm{N}$ & 242 & 242 \\
\hline \multirow{3}{*}{$\begin{array}{l}\text { Metacognition } \\
\text { Skill }\end{array}$} & Pearson Correlation & .873 & 1 \\
\hline & Sign. (2-tailed) & .000 & \\
\hline & $\mathrm{N}$ & 242 & 242 \\
\hline
\end{tabular}

The results of the correlation analysis before learning with the synectics model showed that creative thinking skills and metacognition had a correlation value of 0.718 . While the results of correlation analysis after learning with synectics models showed that creative thinking skills and metacognition have a correlation value of 0.873 . When compared to the two, the results of the correlation analysis after learning with the synectics model were greater than before learning. The correlation between creative thinking skills and metacognition skills is very strong as indicated by the correlation value approaching +1 . With P-value / Sig. equal to $0.00<0.05$, it can be concluded that there is a significant relationship between the two variables. The results of the correlation analysis are then followed by the regression analysis shown in Table 3.

Table 3

The Recapitulation of Regression Analysis Result After Learning with Synectics Model

\begin{tabular}{lcccc}
\hline Model & $\mathrm{R}$ & $\mathrm{R}$ square & Adjusted R Square & Std. Error of the Estimate \\
\hline After & & & & \\
\hline 1 & .873 & .762 & .761 & 3.616 \\
\hline
\end{tabular}

The result of regression analysis after the learning with the synectics model showed $\mathrm{R}$ value of 0.873 . This value can be interpreted that the relationship between the two research variables is in the strong category. Through this table also obtained the value of $\mathrm{R}$ Square or coefficient of determination which shows how good the regression model is formed by the interaction of independent variables and dependent variables. The value of R Square obtained is $76.2 \%$ which can be interpreted that the independent variable 
has an influence of $76.2 \%$ contribution to the $\mathrm{Y}$ variable and $23.8 \%$ is influenced by other factors outside the variable $\mathrm{X}$. Furthermore, also analyzed the regression line equation after learning with synectics model shown in Chart 1

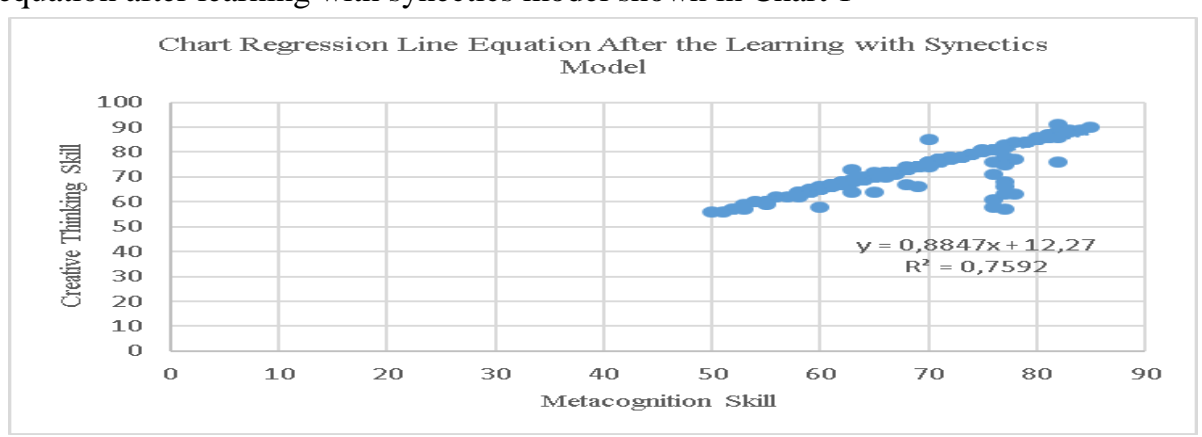

Chart 1

Regression Line Equation After the Learning with Synectics Model

The results of the regression line equation had a constant value of 12.27 and a coefficient of 0.8847 , so the regression line equation is $\mathrm{Y}=12.27+0.8847 \mathrm{x}$. Based on the regression line equation, it is known the influence of creative thinking skills and metacognition skills, that each increase 1 point in the score of metacognition skills resulted in an increase of 0.8847 in creative thinking skills.

Based on the data that have been analyzed, the learning steps based on the developed synectics model that is substantive input, combining direct analogies, comparing analogy and explaining differences, personal analogy, exploring and generating new analogy. The structure of the study presented a phase portrait in the following figure 3 .

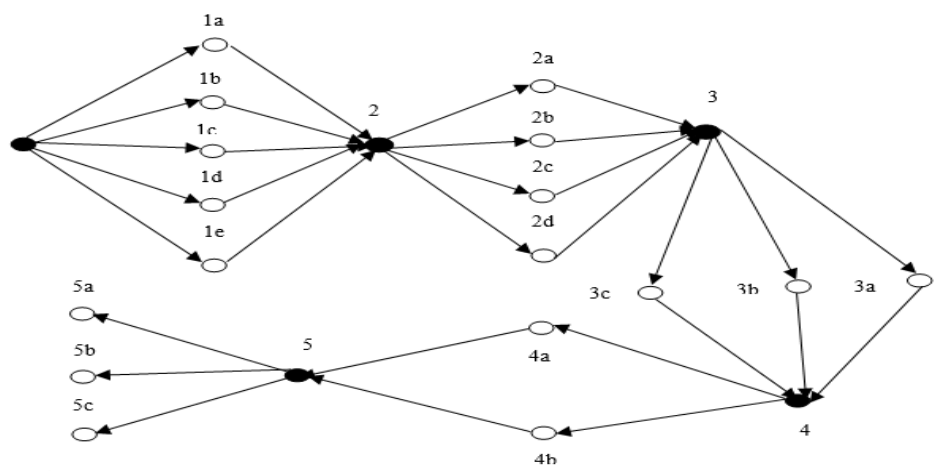

Figure 3

General Phase Portrait Synectics Model

1. Substantive Input

a. Conducting observation 
b. Understanding several pictures/videos

c. Identifying questions as much as possible based on the picture display

d. Knowing definition

e. Understanding characteristics

2. Combining direct analogies, comparing analogies and explaining differences

a. Understanding characteristics

b. Describing analogies

c. Identifying differences

d. Explaining the similarities and the differences in the examples using the chosen analogy

3. Personal Analogy

a. Searching for other examples

b. Assuming oneself to be an object

c. Discussing findings

4. Exploration

a. Explaining findings using one's own language

b. Taking notes on one's findings

5. Raising new analogies

a. Searching for new analogies

b. Exploring the similarities and the differences

c. Presenting ideas to the class

Based on the figure 3 above, the way students think is determined in several phases consisting of several steps in the way of thinking. Each phase has two circles namely black circle and white circle. Each of the black circle describes the activity of students 'thinking in the synectics model, while each of the white circle is the execution of students' thinking in the synectics model.

The results of this study demonstrated that the metacognition and creative thinking skills of the junior high school students from the post-test results were higher than those from the pre-test results. The improved results were obtained since the students began to get used to being trained in working on problems that trigger the development of creative thinking and metacognition skills. In addition, this could not be separated from the implementation of the synectics model. Examples of student work in various categories are presented as follows. 


\section{Subject 1}

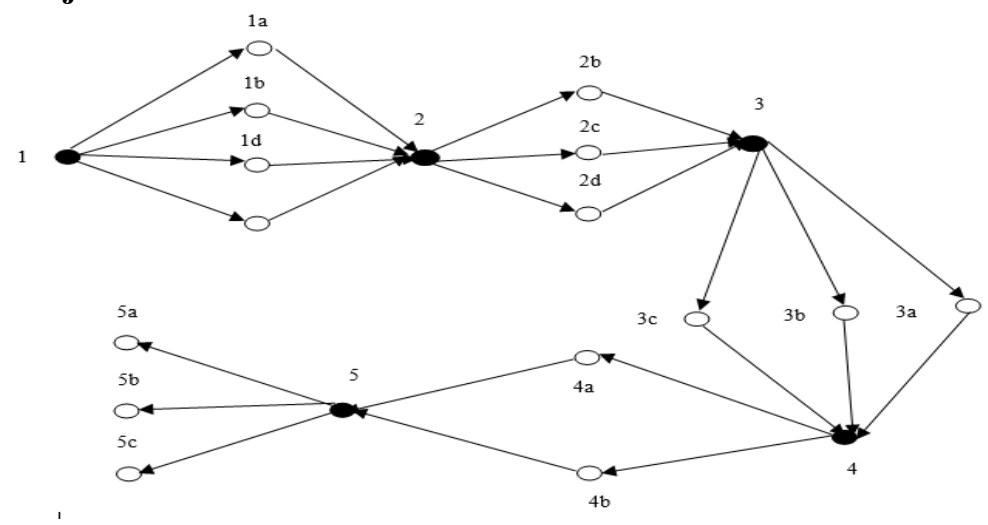

Figure 4

Phase Portrait Synectics Model on Metacognition Skill in Good Category and Creative Thinking Skill in Creative Category

The result obtained from the student's answer to the question on the ecosystem material:

The student elaborated the answer by stating that "In the wild there are many fruits and insects that can be found in various places as food sources to survive". The food chains that might occur according to the student are as follows.

1. Fruits (plant) $\rightarrow$ civet $\rightarrow$ leopard $\rightarrow$ eagle $\rightarrow$ decomposer

2. Flower powder (plant) $\rightarrow$ insect $\rightarrow$ civet $\rightarrow$ big snake $\rightarrow$ eagle $\rightarrow$ decomposer

The following is the answer to the next question:

- Similarities:

1. Civet, snake and eagle are consumers found in both food chains.

2. The process of organism eating another and being eaten by another organism begins with the producer organism and ends with a decomposer

\section{- Differences:}

1. The food chain in Figure 1 is the one in rice field ecosystem, while the food chain in Figure 2 is the one in coffee plantation ecosystem.

2. In the food chain in Figure 1, rice plant acts as a producer. In the first food chain for Figure 2, fruit acts as a producer, whereas in the second food chain, flower powder acts as a producer.

3. In the food chain in Figure 1, the primary consumer is the mouse, the secondary consumer is the snake, and the tertiary consumer is the eagle. In the first food chain for Figure 2, the primary consumer is the civet, while in the second food 
chain the primary consumer is the insect. In the first food chain, the secondary consumer is the leopard, while in the second food chain the secondary consumer is the civet. Furthermore, in the first food chain, the tertiary consumer is the eagle, while in the second food chain the secondary consumers are the big snake and the eagle.

Students with metacognition skill in the good category have been aware of their own thinking and can distinguish the stages of input-elaboration-output of their own thoughts. This can be seen from the answers to the task that showed that they could answer the question in a coherent and systematic manner (see the answer to the food chain that used arrows according to the concept). In addition, they also developed their creative thinking skill which can be seen on the answer sheet which had 2 answers/more than one correct idea which showed that the students used fluency indicator of creative thinking skill. The students also utilized originality and flexibility by giving different solutions to the order of the food chain and providing various answers according to their abilities. After observing the students' task results, the researcher reviewed the results of the interview with subject 1 . The following is the interview quote between the researcher and subject 1 .

Researcher : What is your opinion of the questions given?

Subject 1 : Medium, although some questions are difficult, and some are easy.

Researcher : Are you interested in finding similarities and differences in the analogy exemplified?

Subject $1 \quad$ : Yes, even though finding similarities and differences in an object is not easy because it requires careful analysis.

Researcher : Do you have difficulty in choosing and imagining yourself to be an object?

Subject 1 : No, because I used to imagine what if I were an object. So it is relatively easy for me to imagine being an object, the way I do it is by asking myself what I want to do.

Researcher : Do you find it difficult in searching for a new analogy?

Subject 1 : Of course, I am still not used to looking for examples of similar objects that match the object being discussed, precisely the material of the ecosystem 


\section{Subject 2}

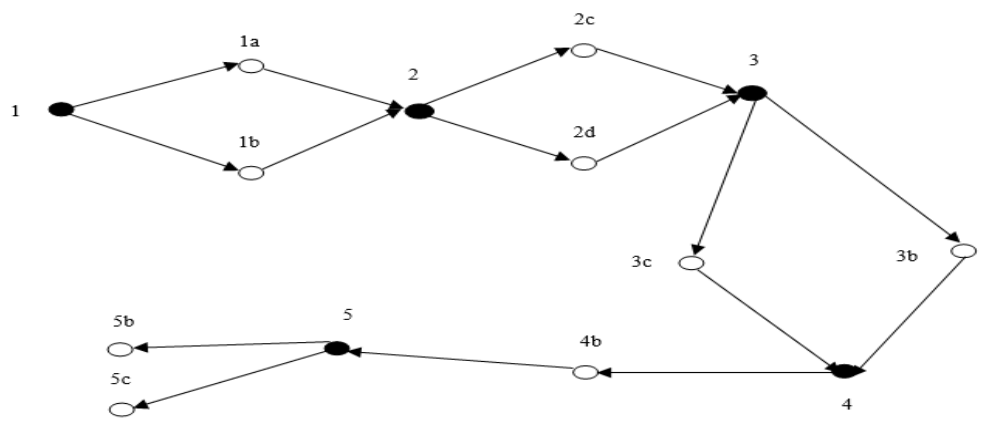

Figure 5

Phase Portrait Synectics Model on Metacognition Skill in Developing Category and Creative Thinking Skill in Creative Category

Answer:

One of the students who were in this category had different answers by stating that "civet not only eats coffee but also cherries and mangoes, and because civet can search for food in various places". The food chains that might occur according to the student are as follows.

1. Coffee bean - civet - leopard - big snake - crocodile

2. Cherries - civet - leopard - big snake - crocodile

The answers to the next question:

- Similarities:

1. Civet and snake are consumers found in both food chains.

2. The process of organism eating another and being eaten by another organism begins with the producer organism and ends with a decomposer

\section{- Differences:}

In the food chain in Figure 1, the primary consumer is the mouse, the secondary consumer is the snake, and the tertiary consumer is the eagle. In the first and the second food chains in Figure 2, the primary consumer is the civet, the secondary consumer is the leopard, and the tertiary consumers are the big snake and the crocodile.

Unlike the answers from subject 1, based on the student's answers above, students with metacognition skill in the developing category were able to answer the questions well even though the delivery of ideas did not use coherent sentences so that the ideas seemed inappropriate. Students in this category can generally help themselves towards their own thinking awareness but need to be encouraged and supported. The biggest encouragement and support are given by teacher as a facilitator and motivator at school. 
When learning, they prefer to listen to teacher's explanation without noting the concept given. When related to the implementation of the synectics learning model, students in the developing category are less able to go through the exploration phase wherein there is an activity to record their findings to result in the development of creative thinking skill. The following depicts the results of interview between the researcher and subject 2.

Researcher : Are you interested when the teacher uses the synectics model?

Subject 2 : Yes, because it relates to the surrounding.

Researcher : When given a question/problem, can you solve it?

Subject 2 : No, I find it difficult to find other examples of the kinds of animals or plants in the food chain that I will make.

Researcher : What do you do when the teacher explains a material?

Subject 2 : I just listen to the teacher's explanation.

Researcher : Do you check your answer after you have finished answering a question?

Subject 2 : Sure, I always check the answers that I have written.

\section{Subject 3}

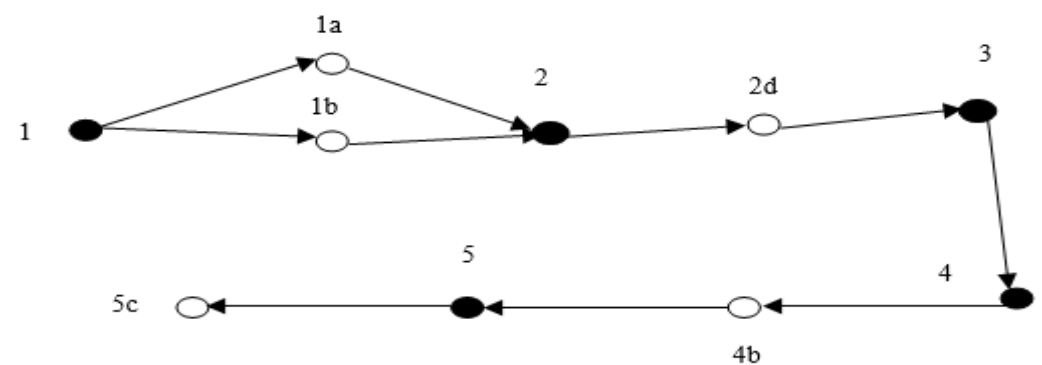

Figure 6

Phase Portrait Synectics Model on Metacognition Skill in Less Capable Category and Creative Thinking Skill in Fairly Creative Category.

Answer:

The answer to the question above is because the producer is the coffee tree. If the coffee runs out, the civet population decreases. If the civet population decreases, coffee trees must be planted again. The food chains that might occur are as follows.

1. Mango, civet, leopard, big snake, crocodile

Producer $\mathrm{CI} \quad \mathrm{C} 2 \quad \mathrm{C} 3 \quad \mathrm{C} 4$

2. Cherry, insect, small reptile, civet, leopard

$\begin{array}{lllll}\text { Producer } & \mathrm{C} 1 & \mathrm{C} 2 & \mathrm{C} 3 & \mathrm{C} 4\end{array}$

The answer to the next question:

- Similarity: 
Both civet and mouse eat plants.

- Difference:

The food chain in Figure 1 is the one in rice field ecosystem, while the food chain in Figure 2 is the one in coffee plantation ecosystem.

Students who have metacognition skill in less capable category are still not able to separate what is thought with how they think, so they have difficulty in solving learning problems. The results of their work will be less optimal since they do not have awareness of the appropriate learning in choosing a strategy or monitoring their own learning. Based on the observation toward the learning, they did not read the task instruction and had not been able to choose important information that was in accordance with the subject matter. As a result, the task was not done properly. Related to creative thinking skill, students who are in the fairly creative category have been able to meet fluency indicator since they are able to answer the questions correctly. However, in light of their low capacity of metacognition, the answers are less coherent and systematic. This can be proven through the interview between subject 3 and the researcher. Based on this finding, it is evident that creative thinking and metacognition skills interact each other.

Researcher : Have you ever had difficulty in solving problems?

Subject 3 : Yes, sure.

Researcher : Can you explain the food chains you have wrote in the answer sheet?

Subject 3 : Mango (producer), civet (Consumer I), leopard (Consumer II), big snake (Consumer III), crocodile (Consumer IV)

Cherry (producer), insect (Consumer I), small reptile (Consumer II), civet (Consumer III), and leopard (Consumer IV)

Researcher : In your opinion, how was your answer?

Subject 3 : I have answered the question correctly.

Researcher : In working on the question, did you read the question several times?

Subject 3 : Not always. Mostly I only read the question once.

\section{DISCUSSION}

Scores obtained from students are categorized to determine the effect of model synectics on creative thinking skills and metacognition skills and to find out the relationship between creative thinking skills and metacognitive skills. From the obtained data, creative thinking skill is in high category while the average score of metacognition skill is in good category. Based on the data processing, it is known that minimum score and maximum score on creative thinking skill and metacognition skill of students are varied. The obtained score shows that there are no junior high school students with zero creative thinking skill. This is in line with Kaufman's (2016) statement that if someone has original and precise thinking, thus he can be said as having creativity. The result of this study also shows that there are no junior high school students who do not have metacognition skill since every indicator got its score even if the score was not perfect. The results of a similar study conducted by Suratno and Kurniati (2018) showed that junior high school students generally mastered satisfying, yet not perfect metacognition skill. In the present study, the students tended to plan, revise, and evaluate, but they did 
not re-examine their responses during planning, nor did they provide logical reasons when determining the steps in solving the given problem. This happens because the metacognition strategy is not used well to develop the level of thinking, change scientific concepts and principles in solving problems (Hargrove \& Anthony, 2008). The use of metacognition strategies triggers a person's cognitive development, so it is very important to develop along with the educational process. Given its very important role and being not inherited skill, teacher should instill metacognition skill in the minds of students through direct learning. Through direct learning, metacognition strategies can also develop students' academic achievement, metacognition skill, and especially develop creative thinking skill (Hargrove \& Anthony, 2008).

Junior high school students with high metacognition skill have the knowledge of the cognitive skill that they have. Besides, they learn faster and harder using a certain strategy which involves metacognition. Metacognition skill affects students' intelligence and their creative thinking process improvement (Hargrove \& Anthony, 2008). Based on the analysis of the correlational result of this study, the probability score of creative thinking skill and metacognition skill is $0.000<0.05$. Thus, there is a significant correlation between them. The correlation between creative thinking skill and metacognition skill is 0.873 . That number shows a strong correlation between creative thinking skills and metacognition skills because the $\mathrm{R}$ score is above 0.05. Meanwhile, the sign "*” shows that the higher metacognition skill means the higher creative thinking skill, vice versa. This can occur as the components of creative thinking involve metacognition skill which includes planning and evaluation (Glover et al, 1989). The results of previous studies reveal that creative thinking and metacognition skills have a significant correlation. For instance, the results of the study conducted by Coutinho (2006) show that the use of strong metacognition strategies, combined with high cognitive needs, is expected to be a strong predictor of performance. Similar results are also mentioned by Alamouti \& Abolghasemi (2017) that using metacognition strategies effectively develops creativity and academic achievement.

The empowerment of creative thinking and metacognition skill is a must (Chan, 2007). Metacognition skill and creative thinking skill have to be done explicitly in higher education level to stimulate professional creative potential in the future (Lizzarraga \& Baquedano, 2013). Metacognition skill and creative thinking skill are skills needed in class and can be improved using learning approaches either in a group or individually (Gomez, 2007). There are some ways which can be taken to improve someone's skill especially creative thinking skill and metacognition skill by implementing certain lesson (Okpara, 2007). One of the learning models that can empower students' metacognition and creative thinking skills is synectics model. Syntax model which involves analogy activity can empower metacognition skill and creative thinking skill because students are able to remember the concept in a new way. Students are able to use their words, relate knowledge learned with daily life and synthesize concept in a better way to improve their understanding (Khan \& Mahmood, 2017). That is supported by Jones's (2011) argument the use of synectics model is an effective method to improve conceptual understanding which is one of the aspects of metacognition skill. 
In the reality, the empowerment of metacognition skill nowadays is not much done. It happens because of teacher's lack of knowledge in realizing that metacognition skill can influence students' learning process. Besides, teacher does not know the proper way to improve students' creativity in learning process inside the class (Laius \& Rannikmae, 2014). Many of the students often do not realize and know their creativity. Therefore, they think that they are only creative in certain field (Sternberg \& Sternberg, 2012). That what makes creative thinking and metacognition skills are less improved. All in all, based on the findings of this study, training or activity program is expected to be held either in school or it's surrounding to support students to empower their creative thinking and metacognition skill to improve well.

\section{CONCLUSION}

The results of this study have shown that in general the mean of creative thinking skill after learning with the synectic model ranges from a score of 68.14 , while the mean of metacognition skill is 72.48 . Furthermore, the correlation analysis shows that creative thinking and metacognition skills have a correlation value of 0.873 . This indicates that there is a strong correlation between creative thinking and metacognition skills. The correlation result has a significance value of 0.000 , which means that the correlation result is very significant. The results of the regression line equation have a constant value of 12.27 and a coefficient value of 0.8847 , so the regression line equation is obtained in the form of $\mathrm{Y}=12.27+0.8847 \mathrm{X}$. Through this equation, it can be seen that each increase of 1 point in the score of metacognition skill generates an increase of 0.8847 in creative thinking skill, and vice versa.

\section{ACKNOWLEDGEMENT}

We gratefully acknowledge the support of FKIP-University of Jember of year 2019.

\section{REFERENCES}

Alamouti, F. M., \& Abolghasemi, S. (2017). The effectiveness of Metacognition Strategies on Creativity and Academic Achievement of Male Grade Three High School Students in Tonekabon, Iran. Sindhological Studies, 70-73.

Alismail, H. A., \& McGuire, P. (2015). 21st Century Standards and Curriculum: Current Research and Practice. Journal of Education and Practice, 150-154.

Cachia, R., Ferrari, A., Mutka, K. A., \& Punie, Y. (2010). Creative Learning and Innovative Teaching Final Report on the Study on Creativity and Innovation in Education in the EU Member States. Luxembourg: Publications Office Of the European Union.

Chan, D. W. (2007). Creative Teaching in Hong Kong Schools: Constraints and Challenges. Educational Research Journal.

Coutinho, S. A. (2006). The Relationship between the Need for Cognition, Metacognition, and Intellectual Task Performance. Educational Research and Reviews, 162-164. 
Eristi, B., \& Polat, M. (2017). The Effectiveness Of Synectics Instructional Model On Foreign Language Vocabulary Teaching. International Journal of Languages' Education and Teaching, 59-76.

Fitriani, S., \& Yarmayani , A. (2018). Development of Rubric Creativity Thinking Skill Senior High School In Mathematical Problem Solving. Mosharafa, 33-38.

Flavell, J. H. (1979). Metacognition and Cognitive Monitoring : A new area of cognitive-developmental inquiry. American Psycologist, 906-911.

Glover, A, J., Ronning, R, R., Reynolds, \& Cecil. (1989). Handbook of Creativity. New York: Springer US.

Gomez, J. G. (2007). What Do We Know About Creativity? The Journal of Effective Teaching, 31-43.

Griffin, P., McGaw, B., \& Care, E. (2012). Assessment and Teaching of 21st Century Skills. London, New York: Springer.

Hargrove, \& Anthony, R. (2008, Juli 16). Creating creativity in the design studio: assessing the impact of metacognition skill development on creative abilities. Retrieved from http://www.lib.ncsu.edu/resolver/1840.16/3048

Johnson, P. (2009). The 21st Century Skills Movement. Educational Leadership, 11.

Jones, C. S. (2011). Applied synectics to teach community development for living and learning communities to resident advisors and community assistants at California State University Monterey Bay. California: Capstone Projects and Theses.

Kaufman, J. C. (2016). Creativity 101, Second Edition. New York: Springer Publishing Company.

Khan, A. A., \& Mahmood, N. (2017). The Role of the Synectics Model in Enhancing Students' Understanding of Geometrical Concepts . Journal of Research and Reflections in Education, 253-264.

Kotzer, S., \& Elran, Y. (2012). Learning and teaching with Moodle-based E-learning environments, combining learning skills and content in the fields of Math and Science \& Technology. 1st Moodle Research Conference, (pp. 122-131). Israel.

Laius, A., \& Rannikmae, M. (2014). Longitudinal Teacher Training Impact on Students' Attributes of Scientific Literacy. International Journal of Humanities and Social Science, 63-72.

Lizzarraga, M. L., \& Baquedano, M. T. (2013). How creative potential is related to metacognition . European Journal of Education and Psychology, 69-81.

Nichols, J. R. (2017, Agustus 29). 4 Essential Rules Of 21st Century Learning. Retrieved from https://www.teachthought.com/learning/4-essential-rules-of-21stcentury-learning/ 
Okpara, F. O. (2007). The Value of Creativity and Innovation Entrepreneurship. Journal Of Asia Entrepreneurship and Sustainability.

Ramadhani, S., Ansari, K., \& Hadi, W. (2017). The Effect of Synectics Learning Model and Vocabulary Mastering to Students Writing Poetry Skill in Grade V SDN 066041 Medan Academic Year 2016/2017. IOSR Journal of Research \& Method in Education (IOSR-JRME), 80-88.

Schraw, G., \& Moshman, D. (1995). Metacognition Theories. Educational Psychology, 351-371.

Sevilla, C. G., Ochave, J. A., Punsalan, T. G., Regala, B. P., \& Uriarte, G. G. (1984). An introduction to research methods. Manila, Philippines: Rex Book Store.

Sternberg, R. J., \& Sternberg, K. (2012). Cognitive Psychology, Sixth Edition. United States Amerika: Wadsworth, Cengage Learning.

Suratno, \& Kurniati, D. (2018). Student's Metacognition Knowledge in Solving Mathematics-Science Problem on Themes Concerning Coffee. Advanced Science Letter, 429-431.

Walker, J. (2013). A PESA Story. Educational Philosophy and Theory, 752-756.

Weiping, H., \& Philip, A. (2002). A scientific creativity test for secondary school students. International Journal of Science Education, 389-403.

Yusnaeni, Corebima, A. D., Susilo, H., \& Zubaidah, S. (2017). Creative Thinking of Low Academic Student Undergoing Search Solve Create and Share Learning Integrated with Metacognition Strategy. International Journal of Instruction, 245-262. 